\title{
SOUTH-VERTING ITALIAN STUDIES: AN INTRODUCTION
}

Joseph Pugliese ${ }^{1}$

Marcello Messina ${ }^{2}$

\section{What would constitute} identity unmarked by race? What are the charged lines of desire that would work so insistently in both the marking and erasure of the relations of racialised power that embody the broad range, both hegemonic and subaltern, of Italian identities - within and without the always fraught space of nation?

The Italian nation-state stands to provoke these urgent questions, precisely through an identifiable double movement that entails the disavowal of race and whiteness and, simultaneously, through its virulent mobilisation of both categories in the marking of bodies, identities and spaces. Situating these racially-loaded questions within the Italian peninsula, its islands and its diasporic reaches, we contend that what drives this seemingly contradictory doublemovement of investment in race and its simultaneous disavowal is the engine of whiteness - as the very racial category of power, entitlement and prestige that needs to be secured and that, strategically and by definition, must elide its status as the superordinate racial category that attempts to hierarchise, position and govern all other racial categories.

All the other embodied racial categories, inscribed within the violence of this double movement, are clearly, in their non-negotiably avowed and seemingly self-evident chromatism, a priori racialised. Here whiteness can be seen to perform a movement self-

1 Doutor em Estudos Anglísticos pela University of Sydney (1992). Diretor de Pesquisa do Departamento de Media, Music, Communication and Cultural Studies da Macquarie University, Sydney, Australia.

2 Doutor em Composição Musical pela University of Leeds (2013). Bolsista PNPD e Professor Colaborador do Programa de Pós-Graduação em Letras: Linguagem e Identidade da Universidade Federal do Acre. 
effacement and disavowal that strives to excise its ineluctable subsistence within the very lexical set of race from which it draws its animating function. To draw on a Derridean term and to ensnare it within the orbit of race, we are here in the realm of an Italian "white mythology"3 that inflects bodies, histories, spaces, culture and all the other entities that are crucial in constituting the heterogeneous assemblage of a racialised nation-state desperate to purchase and secure its European-white status by repeatedly mobilising southern bodies to mark the borders of all that is not Europe.

In this special issue on the Italian South, we track the operations of this racialised white mythology along a number of geopolitical axes in a collective attempt to visibilise the relations of physical and epistemic violence that attend the embodiment of this racial formation in both its situated locations and across its geographies of dispersal. The very animating logic that brought this special issue to fruition, in fact, finds its locus in this movement of diasporic (dis)location and dispersal. The idea of this special issue originated in late 2014, over an intercontinental phone call between the UK and Australia. It was then consolidated during a number of meetings in Sydney, between 2015 and 2016. Lastly, this work took its final editorial form in the South-western Amazonian city of Rio Branco. The fact that no single page of this collective work on the South of Italy was conceived within the territorial limits of the Italian state should not be taken as a contradiction. On the contrary, this collective work attempts to retrace and re-join disparate and oftensilenced histories along the multiple geographical axes of southern Italian diaspora. That all the southern writers of this special issue inhabit diasporic positions in relation to the

3 Derrida deploys the term "white mythology" in his deconstruction of the status of metaphor in philosophy; this racially loaded term, however, remains racially unmarked in his essay (cf. DERRIDA, 1986, pp. 207-272). 
Italian nation-state merely serves to underscore the inarguable fact that the South, and the Italian nation-state, cannot begin to be rendered intelligible outside of a frame of enforced deportations, mass migration and diaspora.

The place names - UK, Australia and Brazil - that inscribe the production of this special issue are not, as might otherwise appear, purely arbitrary in their relation; rather, this seemingly random series of nation-state names is crucially inscribed by larger geopolitical relations of power: the UK, specifically England, as the originary locus of empire and British settler-colonial expansion; Australia as one of the key settler-colonial states founded by the British Empire; and Brazil, another crucial settler-colonial state brought into being by the Portuguese Colonial Empire. Caught within layered and often contradictory histories of both internal colonialism (as evidenced both by the process of Italian Unification and by the ongoing, violent colonisation of Amazonia and Australia) and external imperialcolonial expansionism (the UK, Australia and Brazil), the diasporic writers of this special issue variously attempt to name and expose these complex entanglements and formations.

The embodied southern collective of diasporic supplements that generated this special issue's essays may be seen, precisely because of its diasporic status, as nothing more than a mere accretion inhabiting the extra-territorial borders of the Italian nationstate. Yet, in keeping with the complex logic of the supplement, these diasporic fragments (that seem marginal to, because outside of, the Italian nation-state) function to call into question the very selfidentical status of the Italian nation's (disavowed) racial identity. The supplementary work of the essays in this collection is, in an overarching manner, preoccupied with evidencing how the categories of race and whiteness are 
anything but inconsequential accretions to Italian identity. Rather, and again in keeping with the logic of the supplement, the essays demonstrate, in their collectivity, that what has been disavowed, marginalised and/or invisibilised is actually foundationally constitutive of the heterogeneous and fractured assemblage that comes under the otherwise homogenising imprimatur of "Italian identity": namely, race and whiteness.

\section{South-verting}

Italian Studies literally means freeing them from the Northnormative pressure on which the very concept of Italianness is predicated. In this sense, our positionalities as émigrés, expats, exiles and first-, second- or third-generation diasporic subjects allow for the articulation of what is largely unspeakable within the territorial boundaries of the Italian Republic, reiteratively, the violent operativity of race in tracing the geo-biopolitical demarcation between the North and the South.
As the essays in this special issue evidence, narratives of race and whiteness have historically operated towards the perpetration, legitimisation and naturalisation of various types of interventions throughout the 150-odd years since Italian Unification. In the context of the South, these racialised interventions have worked to produce both economic and political disenfranchisement and paternalistic regimes of welfare dependency and charitable benevolence. Having said that, we categorically refute any toxic representation of the South based on the racially loaded discourse of assistenzialismo ("welfarism"), centred on the cliché of the South as a parasiting burden that voraciously consumes most of the resources produced by the North. In fact, figures that range from ordinary budget spending to endlessly and transversally criticised extraordinary interventions such as the Cassa per il Mezzogiorno and the current EU Convergence Objective demonstrate that the amount of 
(total and per capita) resources that reaches the South is actually a fraction of the money that is invested in the North (LEPORE, 2012; POLVERARI, 2013; MAGNATI, ROSA \& SABATINI, 2004). While the South was thus uninterruptedly plundered and impoverished, racialised representation of it as Italy's palla al piede ("ball and chain"), contributed to justify militarised interventions by the North that have resulted in massacres, practices of collective punishment, sexual assault and violence, and mass incarceration.

Apart from some important exceptions, contemporary academic narratives on Italy repeatedly ignore the critical importance of addressing these largely silenced histories. The general tendency, indeed, is to continue to ignore Southern genealogies, regardless of the drive by both diasporic and internal Southern communities to address, confront and elaborate these histories.

In addition, traditional scholarship related to the so-called Bel Paese takes the discursive centrality and normativity of the country's Northern and Central regions as self-evidently constitutive of Italian identity. Although deconstructions of this North-normative orientation abundantly exist as far as Southern identity per se is concerned, academics often find themselves forced to start back from the North when facing broader issues related to politics, culture and identity, as the South is not usually construed as capable of producing critical and theorised analyses of these same issues. In this sense, general and allencompassing narratives of Italian culture and society are seen exclusively to issue from Northern Italian urban centres and their glamourous scenarios and internationally commodified artefacts. The blurb of a recent conference in and on Milan is illuminating in this sense:

Milan has been at the heart of modern Italy's cultural transformations. Considered the "capitale morale" of the country since the nineteenth 
century, the city has also acquired the role of a financial capital, becoming the "città operosa" par excellence in the collective imagination. It has become the home of prominent intellectual figures and a place where cultural institutions as well as major national newspapers and publishing houses have increasingly been concentrated. The city has historically presented itself as a hub for members of the intellectual professions and, during recent decades, for the television, fashion and design industries. Milan has also been a gateway for Italy, filtering cultural innovation and transformation from abroad, and cyclically has acted as a point of attraction or connection for diverse migration fluxes. Our conference explores Milan as a crossroads of cultures and a fertile ground for artistic experimentation and cultural exchange, also emphasising the role of the industrial context and professional expertise in producing, developing or steering transformations over the last two centuries, with a privileged focus on contemporary developments (UNIMI, 2016).

Let us deploy the most basic rudiments of discourse analysis here. The first sentence locates
Milan in the temporal dimension of modernity and progress, implicitly in contradistinction to the always already backward, stagnant and undeveloped South. The second sentence celebrates Milan as the locus of morality and industriousness, in contradistinction to a South that is inveterately immoral and lazy. The third, fourth, fifth and final sentences highlight the role of Milan as the core of several centripetal forces that have to do with intellectual excellence, cultural industries, artistic experimentation, industrial and economic productivity, and so forth. The deployment of such terms as "heart", "home", "capital" and "hub" in this description of Milan operates to establish the binarised and hierarchised geography of centre/margin, North/South. In other words, Milan's centralised positionality as the modern, dynamic and industrious "moral capital" of Italy is implicitly set against a number of backward, immobile, indolent and immoral peripheries. As Gabriella Gribaudi notes, everything that 
is other to the Northern Italian ideal-norm, as tautologically constitutive of "Italian" identity, is stereotypically assigned to the South (1997). If there is a white mythology operative in this celebratory portrait of Milan, then it can be seen to perpetrate the following untenable fictions: Milan as a type of pristine space of whiteness unmarked by immorality, corruption or crime; Milan as the model city set on teleological trajectory of industriousness, development and economic and cultural success; Milan as the white beacon that transcends the moral, economic and political morass that is, implicitly, the South.

The tacit knowledges that enable the construction of this racialised Northern fiction are acutely exposed when counterpointed by a very different blurb. Even as we write, we receive the following call for papers on Naples:

From Boccaccio to Ferrante, from Assunta Spina to Gomorra. La serie, Naples has aroused both interest and repulsion and has been a source of inspiration for Italian and international writers and directors. For some Naples has become a symbol of freedom and mundane joy, whereas for others the urban environment has represented mere anguish, fear, and homelessness. This panel is open to contributions on any period of Italian literature and cinema (AAIS, 2017).

The unqualified celebratory tone of the Milan conference is here replaced by a series of critical qualifications, whereby the inevitable "interest" in the city is immediately attenuated by the "repulsion" it prompts - as though 'anguish, fear, and homelessness' only ever inhabited the always already compromised cities and towns of the South; as though, moreover, the thousands of subjects of the Global South - refugees, asylum seekers, migrants and so on - that live in both the centres and the peripheries of most Northern cities in racialised conditions of poverty, homelessness and squalor could be magically airbrushed out of existence. There is, a fortiori, no anguish, 
fear or homelessness to be found in the utopian city of Milan: all of this dystopian detritus is what only inheres in the bad lands of the South. Academic calls that involve southern Italy are usually pitched in these terms, so that conference committees can welcome us to "Palermo, a city [that is] beautiful and complex," (AATI, 2017) where "complex" operates as code for "dangerous, corrupt, filthy, crime-ridden" and so on; or they can invite us to reflect on economic development in an allegedly "hostile environment" (UNICAL, 2017) such as Calabria, where the natives, famously, are intrinsically violent, barbaric and indifferent to the rule of law. Far from staging a critique against colleagues who are keen to trigger debates on the South, we draw on these blurbs in order to underscore the bipolar and hierarchised relations of power that delineate the racially differentiated cultural geographies of the North and the South. These blurbs, furthermore, demonstrate just how deeply embedded these tacit racialised knowledges are across the different discourses concerned with representing the South, including discourses that issue from the South and that unreflexively reproduce internalised forms of epistemic self-violence. All these textual manifestations confirm the set of persisting racialised assumptions that are evoked and repeatedly reproduced in Italy in writings engaged in representing Italian identity and the South.

This special issue situates itself within the ongoing scholarly project of theorising the Italian South in the context of the heterogeneous cultural histories, non-European genealogies and discursive practices otherwise effaced by hegemonic conceptualisations of the Italian nation. The essays in this special issue work to recover and materialise alternative histories that at once inform and embody southern cultural practices, identities and so on. Collectively, the essays are concerned with critiquing and overturning 
Northernist notions of the South as an ontologically fixed, impermeable and selfreferential construct cut off from the multiplicity of historico-cultural mediations that actually constitute its identity: including diasporic, North African, Arab, Muslim, Albanian, Spanish and so on. The essays are informed by a range of critical theories that are at once reworked and resignified once they are situated in the context of the South and, crucially, that establish and strive to maintain international lines of solidarity with other contestatory and liberatory movements.

Finally, through critical analyses of a range of diverse cultural practices, texts and media, the essays work to bring into visibility and contemporise the alternative genealogies that continue to animate the South and, indeed, that work geopolitically to pluralise it into so many Souths that breach and defy, literally South-vert, the dominant, Northernist stereotypes of the region and its diasporas.

\section{References}

AATI (American Association of Teachers of Italian), Messaggio ai convegnisti, 2017. https://goo. $\mathrm{gl} / \mathrm{pBFmbk}$

AAIS (American Association for Italian Studies),Representations of Naples in Italian Literature and Cinema, 2017. https://goo. $\mathrm{gl} / \mathrm{h} 5 \mathrm{XRJC}$

DERRIDA, J. Margins of Philosophy. Brighton: The Harverster Press, 1986. GRIBAUDI, G. Images of the South: The Mezzogiorno as seen by Insiders and Outsiders. In LUMLEY, R.; MORRIS, J., (orgs.) The New History of the Italian South: The Mezzogiorno Revisited, Exeter: University of Exeter Press, 1997, pp. 83-113.

LEPORE, A. L'andamento della spesa per l'intervento straordinario nel Mezzogiorno d'Italia, dalla golden age alla fine del XX secolo. Revista Española de Historia de la Contabilidad, $n$. 16, 2012, pp. 76-119.

MAGNATI, P.; ROSA, G.; SABATINI, M. I divari economico-sociali nell'Europa a 15. In: GIUSTINO, E. (Org.) Le regioni meridionali e l'Europa a 25. Napoli: Alfredo Guida, 2004, pp. 223-244.

POLVERARI, L. Policy Rhetoric versus Political Reality: Has the Italian State Given Up on the Mezzogiorno? Regional \& Federal Studies, vo. 23, n. 5, 2013, pp. 571590.

UNICAL (Università della Calabria), 
Capitalist Development in Hostile Environments, 2017. https://goo.gl/KySEUm

UNIMI (Università degli Studi di Milano), Milan Crossroad of Cultures, 2016. https://goo.gl/ Hw9d5o 